\title{
Performance of Different Radish Varieties under Foothill Region Dehradun, Uttrakhand, India
}

\author{
Senjem Semba ${ }^{1,2 *}$, Renu Rana ${ }^{1}$, Tabalique Yumkhaibam ${ }^{2}$ and Md. Ramjan ${ }^{2}$
}

${ }^{1}$ College of Agriculture Science and Technology Selaqui, Dehradun (Uttarakhand), India (Affiliated to HNB Garhwal University Srinagar, Garhwal Uttarakhand), India

${ }^{2}$ College of Horticulture and forestry, Pasighat-791102, Arunachal Pradesh, India

*Corresponding author

\section{A B S T R A C T}

The present study was conducted to study the performance of six different varieties for foothill region Dehradun, Uttrakhand. The varieties were Korean cross, Long red, Menu Early, Snow white, Scarlet red globe and Local check. The

\section{Keywords}

Radish, Yield, Varities, Dehradun

Article Info

Accepted:

10 June 2019

Available Online:

10 July 2019 analysis revealed highly significant differences Maximum plant height (60.53), leaf length $(32.55 \mathrm{~cm})$, fresh weight of leaves $(97.61 \mathrm{~g})$, fresh weight per plant $(242.25 \mathrm{~g})$ and total dry weight content $(21.05 \mathrm{~g})$ was found maximum in Menu Early, while for length of roots $(34.63 \mathrm{~cm})$, fresh weight of root $(160.16 \mathrm{~g})$, total yield of radish root $(46.91 \mathrm{t} / \mathrm{h})$ and dry weight of radish root $(10.96 \mathrm{~g})$, the variety Korean cross performed better than the other varieties. The maximum width of the root $(4.44 \mathrm{~cm})$ was recorded in variety Scarlet red globe. So the variety Snow white, Korean cross and Menu Early were found to be superior for yield and quality attributes and is recommended to grow under hill region of Dehradun. Among genotypes for all the traits, per cent germination (65.47\%), yield of leaves $(25.13 \mathrm{t} / \mathrm{h})$, total yield $(69.47 \mathrm{t} / \mathrm{h})$ and dry weight of leaves $(10.17 \mathrm{~g})$ was found maximum in Snow white, while maximum number of leaves per plant 18.55 was observed in Local check.

\section{Introduction}

Radish (Raphanus sativus L.) belongs to the family Cruciferae with chromosome number $2 \mathrm{n}=2 \mathrm{x}=18$ genus Raphanus and species sativus believed by some taxonomist to be originated from China (Werth, 1937; Rubatzky and Yamaguchi, 1997; Mallikarjunarao et al., 2015). Radish is a dicotyledonous, biennial herbaceous plant that is usually grown as an annual vegetative crop for its enlarged fleshly taproot (Zaki et al., 2012). It is a popular root vegetable crop in tropical, sub -tropical and temperate regions. It is grown for tender roots which is cooked or eaten raw. Radish has pungent taste when eaten raw which is due to presence of glucosinolates and the major glucosinolates 
present in radish is isothiocyanates. It is good source of vitamin and minerals like ascorbic acid, calcium, potassium and phosphorus. Radish is predominantly a cool season vegetable crop but Asiatic types can tolerate higher temperature than European varieties. Being a cool season crop it is sown during winter from September to January in Northern plains. In the climatic condition of Indian Peninsular India, radish can be grown almost all the year round except for few months of summer. The growth and yield of radish greatly depends on soil and climatic condition. Radish is grown in most types of soil if it is well managed. It is grown under a wide range of climatic conditions. Performance of radish genotypes varies with the region, season and other growing condition. Thus identification of a suitable genotype suited to growing condition is most important for successful commercial cultivation especially for unstable climatic conditions of hills.

The diversity of cultivated radish plants species depends upon mutation and hybridization, range of dispersal and processes of cultivation and domestication (Yamane et al., 2009; Heiser, 1998). Introduction of improved varieties and attempts of seed production utilizing such introduction varieties may lead to loss of diversity of Land races (Nisar and Ghafoor 2011). Radish is a short life cycle and possesses many genetic markers, male sterility and a multi-allelic incompatibility system due to which it is becoming useful in molecular genetics for experimentation (Crisp, 1995). Adequate description of the diversity of radish should result in much greater emphasis on both conserving and exploiting this variation. Indigenous cultivars are mostly white having a triangular cylindrically shape roots with more pungent taste than the introduced type. Generally, genetic variability of radish germplasm is not much investigated and only a few studies have been reported. The production of radish is $3061000 \mathrm{MT}$ at an area of $209000 \mathrm{Ha}$ in India (NHB, 2018).

\section{Materials and Methods}

Field experiment was conducted at Doon (PG) College of Agriculture Science and Technology, Dehradun (Uttrakhand), during Rabi season of 2014. It is situated at $30^{\circ} 21^{\prime} 31^{\prime}, \mathrm{N}$ latitude and $77^{\circ} 50^{\prime} 40^{\prime}{ }^{\prime} \mathrm{N}$ longitudes with an altitude of $516.5 \mathrm{~m}$ above mean sea level. The texture of the soil is sandy loam. "Performance of different radish varieties under foothill region Dehradun, Uttrakhand". The genotypes cultivated are namely: - 1) Korean Cross (R.K seed form's (Regd)) 2) Long Red. (New Rama Seed Corporation) 3) Menu Early. 4) Snow White (New Rama Seed Corporation). 5) Scarlet red globe (Indica hybrid seed) 6) Local check. The soil was sandy loam with $\mathrm{pH}$ ranges from 6.07.0 with organic carbon content of 0.82$0.85 \%$. The radish was planted Randomized Block design (RBD) with 4 replications whole experimental area was $150 \mathrm{~m}^{2}$.The lay-out was prepared adopting randomized block design. Allocation of different treatments was made to various plots by using random sampling. Sowing was done on February during rabi/winter season. Seeds were dibbled half way down the ridge at a distance of $10 \mathrm{~cm}$ in the soil. The distance of plant to plant is $10 \mathrm{~cm}$ and row to row $15 \mathrm{~cm}$. Thinning was done at 8 days after sowing. The crop was harvested at full maturity, when the soil moisture was optimum. The plants were pulled out without damaging the roots from the net plots. The soil adhering to the roots was removed. Observations were recorded for Germination percentage, Number of leaves, Height of the radish plant $(\mathrm{cm})$, Root length $(\mathrm{cm})$, Root diameter $(\mathrm{cm})$, Fresh weight of leaves $(\mathrm{g})$, Dry matter content of leaves ( $\mathrm{g}$ ), Fresh weight of roots $(\mathrm{g})$, Dry matter contents of roots, Total fresh weight of plants $(\mathrm{g})$, Total dry weight of plants (g), Yield per hectare (tone). The data 
were analyzed according to the Randomized Block Design

\section{Results and Discussion}

\section{Growth attributes}

\section{Germination percentage}

It was found that the maximum germination percentage to variety Snow white $(65.47 \%)$ (Table 1), which may be to earliness in seed germination compared with rest of the varieties. The germination percentage was closely followed by Korean cross $(60.11 \%)$, Local check $(53.26 \%)$ and long red $(51.18 \%)$ but the germination percentage was quite low for Menu early (44.93\%). The lowest germination percentage among the six varieties was recorded to the variety Scarlet red globe $(27.380 \%)$. The higher germination percentage in the variety Snow white $(65.47$ $\%$ ) compared to the variety Scarlet red globe $(27.3 \%)$ may be attributed to spacing, soil moisture, temperature, seed vigour and dormancy of seed which usually influence the days to germinate and germination percentage.These reasons were also mention by Lavanya et al., (2014). Meanwhile, Singh and Singh (2012) also found heritability estimation high for germination percentage and final germination \% show dominant effect of genes and thus bear significant effect on determining genetic variability among different radish genotypes.

\section{Plant height}

The maximum height per plant was recorded to Menu early $(60.53 \mathrm{~cm})$ which is closely followed by Snow white $(54.98 \mathrm{~cm})$, Korean cross $(53.93 \mathrm{~cm})$, Local check $(52.60 \mathrm{~cm})$ (Table 1) but poor height of the variety long red $(44.45 \mathrm{~cm})$ was due to blotting of radish plant due high temperature in its cultivation season. While, the minimum was recorded values were observed in Scarlet red globe $(27.91 \mathrm{~cm})$. These huge difference in the height between Menu early and scarlet red globe is mainly due to difference its morphological character between the two varieties. Due to miniature size in Scarlet red globe compared to other five varieties the variation in height was observed. Naseeruddin et al., (2011) also reported that in its finding that Scarlet red globe $(34.55 \mathrm{~cm})$ recorded the minimum height per plant and snow white recorded the maximum height per plant of $(65.06 \mathrm{~cm})$ after harvesting among the 20 genotypes studied. The significant differences in height may be due genetic variability and heritability of the varieties studied as also reported by Naseeruddin et al., (2011).

\section{Number of leaves}

The data regarding number of leaves per plant also showed significant differences among the varieties. The variation in number of leaves was also reported Naseeruddin et al., (2011) and Dongarwar et al., (2018) which also supports the result of the findings

The data clearly showed that the lengths of leaves per plant were found significant different among all the six varieties tried. The maximum length of leaves per plant was recorded to menu early $(32.55 \mathrm{~cm})$ which was closely followed by Local check $(28.05 \mathrm{~cm})$, Snow white $(25.97 \mathrm{~cm})$, long red $(24.97 \mathrm{~cm})$ respectively. The length of leaves of Korean cross $(18.95 \mathrm{~cm})$ was comparatively less while, Scarlet red globe $(17.46 \mathrm{~cm})$ recorded the minimum the lengths of leaves per plant (Table 1). These differences in length of leaves may be due to the different phenotypic and genotypic variation among the studied varieties. Similar reason was also recorded by Naseeruddin et al., (2011). Naseeruddin et al., (2011) in their traits conducted recorded that Scarlet red globe $(17.01 \mathrm{~cm})$ was found the minimum leave length among the 20 genotype 
studied. The significant differences in leaves length among the varieties may be due heritability and genetic variability as reported by Makhdoomi et al., (2007)

\section{Length of root}

The maximum length of root per plant was recorded to Korean cross $(34.63 \mathrm{~cm})$ and minimum in Scarlet red globe $(10.90 \mathrm{~cm})$ (Table 1). Korean cross been a $F_{1}$ hybrid have superior characters and shows genetic advances compare to five other varieties. Mukhdoomi et al., (2007) mentions genetic gain in the difference of variance in the root length among the different genotype of radish studied. Long red root length was severely affected by blotting, which was affected by unfavourable climatic condition. Scarlet red globe root length was minimum due the miniature size and globular shape of the root. So the difference in length of roots among different varieties depends genetically as well as environmentally Dongarwar et al., (2018) mentions that might be genetical diversity in different varieties and ecological condition leads to the variation in root length which shows similar findings.

\section{Width of root per plant}

The significant variations in width of root per plant were observed among the different varieties studied. The highest width of root per plant was recorded to Scarlet red globe (4.449 $\mathrm{cm}$ ) which was followed by Menu early (3.38 $\mathrm{cm})$, Snow white $(3.34 \mathrm{~cm})$, Korean cross $(3.02 \mathrm{~cm})$, respectively, while, the minimum width of root per plant was recorded to long red $(2.92 \mathrm{~cm})$ (Table 1). Similar variation among the width of the radish root was reported by Dongarwar et al., (2018) which supports the findings. The width in long red was affectively low due to blotting which was due to unsuitable environmental stress in the cultivation period of $20 \mathrm{Feb}$ to 30 May.
Blotting was the main cause for the poor performance of long red variety. The highest width of root was due to globular shape of root in Scarlet red globe whereas the others were thin and long type of root. Rajput et al., (2014) reported the range of variation was high for root size which was due to, genetic variability, heritability and genetic advance. With these the width of root among the studied varieties dependent on genetic variability, heritability, genetic advance and also favourable environmental conditions.

\section{Yield attributes}

\section{Fresh weight of leaves per plant}

The significant variations in fresh weight of leaves per plant were observed among the different varieties studied. The maximum fresh weight of leaves per plant was recorded to Menu early (97.61 g) which was superior over Snow white $(82.20 \mathrm{~g})$, Local check (72.22 g), Korean cross (49.08 g) and long red $(25.76 \mathrm{~g})$ while; the minimum fresh weight of leaves per plant was recorded to Scarlet red globe (21.08 g) (Table 2).

The factors influencing the weight of leaves are leaf length and leaf size or even the nutrient content in the leaves. So the phenotypic and genotypic features of leaf are an important feature in determining the weight of the leaves among different genotypes. Naseeruddin et al., (2011) reported that the minimum fresh weight of leaves per plant among the 20 genotype was Radish Scarlet red globe with (15.02g). Naseeruddin et al., (2011) also concluded that genotypic as well as phenotypic co efficient was high in leaf weight among the varieties. But the poor response by long red was mainly due unfavourable environmental factor. This concludes that the difference in the fresh weight of the leaves was due genetic characters and environmental factors. 
Table.1 Growth attributes data of different morphological parameters

\begin{tabular}{|c|c|c|c|c|c|c|c|c|c|c|}
\hline Treatment & $\begin{array}{c}\text { Germination } \\
\text { Percentage } \\
(\%)\end{array}$ & $\begin{array}{c}\text { Plant } \\
\text { height } \\
\text { (cm) }\end{array}$ & 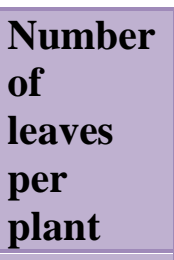 & $\begin{array}{l}\text { Length } \\
\text { of } \\
\text { leaves } \\
\text { (cm) }\end{array}$ & $\begin{array}{l}\text { Fresh } \\
\text { weight } \\
\text { of } \\
\text { leaves } \\
\text { (g) }\end{array}$ & $\begin{array}{l}\text { Total } \\
\text { leaves } \\
\text { yield } \\
\text { (t/ha) }\end{array}$ & $\begin{array}{l}\text { Root } \\
\text { Length } \\
\text { (cm) }\end{array}$ & $\begin{array}{l}\text { Root } \\
\text { Width } \\
\text { (cm) }\end{array}$ & $\begin{array}{c}\text { Fresh } \\
\text { weight } \\
\text { of root/ } \\
\text { plants(g) }\end{array}$ & $\begin{array}{l}\text { Total } \\
\text { root } \\
\text { yield } \\
\text { (t/ha) }\end{array}$ \\
\hline $\begin{array}{l}\text { Korean cross } \\
\left(T_{1}\right)\end{array}$ & 60.11 & 53.94 & 16.20 & 18.94 & 49.08 & 14.40 & 34.63 & 3.02 & 160.16 & 46.91 \\
\hline long red $\left(T_{2}\right)$ & 51.18 & 44.45 & 8.47 & 24.37 & 25.76 & 6.15 & 19.83 & 2.22 & 45.27 & 10.79 \\
\hline Menu early $\left(T_{3}\right)$ & 44.93 & 60.53 & 18.25 & 32.55 & 97.61 & 20.46 & 27.68 & 3.38 & 144.63 & 30.32 \\
\hline Snow white $\left(T_{4}\right)$ & 65.47 & 54.98 & 17.55 & 25.97 & 82.20 & 25.13 & 28.86 & 3.34 & 145.17 & 44.33 \\
\hline $\begin{array}{l}\text { Scarlet red globe } \\
\left(T_{5}\right)\end{array}$ & 27.38 & 27.91 & 9.80 & 17.46 & 21.08 & 2.67 & 10.90 & 4.44 & 46.91 & 5.99 \\
\hline Local check $\left(T_{6}\right)$ & 53.26 & 52.60 & 18.55 & 28.05 & 72.22 & 17.95 & 27.75 & 2.92 & 133.03 & 33.07 \\
\hline CD & 12.5 & 1.17 & 0.68 & 3.09 & 0.35 & 4.15 & 0.35 & 0.25 & 0.59 & 7.85 \\
\hline SE(m) & 4.13 & 0.38 & 0.22 & 1.01 & 0.11 & 1.36 & 0.11 & 0.08 & 0.19 & 2.58 \\
\hline SE(d) & 5.84 & 0.54 & 0.22 & 1.01 & 0.11 & 1.36 & 0.16 & 0.12 & 0.27 & 3.65 \\
\hline CV & 16.39 & 1.57 & 0.31 & 1.43 & 0.16 & 1.93 & 0.93 & 5.27 & 0.34 & 18.08 \\
\hline
\end{tabular}

Table.2 Yield attributes data of different varieties

\begin{tabular}{|c|c|c|c|c|c|}
\hline Treatment & $\begin{array}{l}\text { Total fresh } \\
\text { weight / } \\
\text { plants.(g) }\end{array}$ & $\begin{array}{l}\text { Total yield of } \\
\text { radish/ } \\
\text { (tone/ hectare) }\end{array}$ & $\begin{array}{l}\text { Dry weight } \\
\text { of radish } \\
\text { leaves per } \\
\text { plant (g) }\end{array}$ & $\begin{array}{l}\text { Dry weight } \\
\text { of radish } \\
\text { root per } \\
\text { plant (g) }\end{array}$ & $\begin{array}{l}\text { Total dry } \\
\text { weight } \\
\text { content of } \\
\text { radish per } \\
\text { plant }(g)\end{array}$ \\
\hline Korean cross $\left(T_{1}\right)$ & 209.25 & 61.32 & 7.02 & 10.96 & 17.98 \\
\hline long red $\left(T_{2}\right)$ & 71.03 & 16.96 & 4.05 & 3.57 & 7.63 \\
\hline Menu early $\left(\mathbf{T}_{3}\right)$ & 242.25 & 50.79 & 10.14 & 10.90 & 21.05 \\
\hline Snow white $\left(\mathbf{T}_{4}\right)$ & 227.38 & 69.47 & 10.17 & 10.54 & 20.72 \\
\hline Scarlet red globe $\left(T_{5}\right)$ & 67.99 & 8.67 & 3.05 & 2.77 & 5.95 \\
\hline $\operatorname{local} \operatorname{check}\left(\mathbf{T}_{6}\right)$ & 205.26 & 51.02 & 6.83 & 7.62 & 14.46 \\
\hline CD & 0.50 & 11.90 & 0.20 & 0.39 & 0.62 \\
\hline $\mathrm{SE}(\mathrm{m})$ & 0.16 & 3.91 & 0.06 & 0.13 & 0.20 \\
\hline SE(d) & 0.23 & 5.53 & 0.09 & 0.18 & 0.28 \\
\hline CV & 0.19 & 18.18 & 1.93 & 3.39 & 2.79 \\
\hline
\end{tabular}

Total yield of radish leaves per plant (tone/hectare)

The data clearly showed that the Total yield of radish leaves per plant was found significant different among all the six varieties tried. The maximum Total yield of radish leaves per plant was recorded to Snow white $(25.13 \mathrm{t} / \mathrm{ha})$ while, Scarlet red globe $(2.67 \mathrm{t} / \mathrm{ha})$ was recorded the minimum Total yield of radish leaves per plant. Here, the length of leaf and germination percentage plays a great role to determine the total yield of leaves. The variety snow white performed 
better compared to the Local check (17.95 t/ha) and other four varieties mainly due to its superior seed germination character which increase the yield capacity of the leaf. Whereas the poor performance of Scarlet red globe among the six varieties was mainly due to smaller leaf length and inferior seed germination character.

\section{Fresh weight of radish root per plant}

The significant variations in fresh weight of root per plant were observed among the different varieties studied. The maximum fresh weight of root per plant was recorded to Korean cross (160.16 g) which was superior over Snow white(145.17 g), Menu early (144.63 g), Local check (133.03 g), Scarlet globe $(46.91 \mathrm{~g})$ while the minimum fresh weight of root per plant was recorded to long red $(45.27 \mathrm{~g})$. Korean cross been an $\mathrm{F}_{1}$ hybrid is better and genetically advance then local check performed better in terms of fresh root weight as well as among the six varieties. These indicated that better heritability quality from the parents influences the root weight. Naseeruddin et al., (2011) also mention the relation of heritability with the root weight. But poor root weight in long red was mainly due to unfavourable climatic condition. This concludes that the differences in root weight does not only depend on heritability quality but also depends on environmental factors.

\section{Total fresh weight of radish per plant}

The significant variations in total fresh weight per plant were observed among the different varieties studied. The maximum total fresh weight per plant was recorded to Menu early (242.25 g), which was superior over Snow white (227.38 g), Korean cross (209.25 g), Local check(205.20 g), Long red (71.03 g) while; the minimum fresh weight of root per plant was recorded to Scarlet red globe (67.99 g). These differences in fresh weight could be attributed to overall growth in vegetative structure of difference varieties which is influence by genetic makeup in the varieties and also depends on their environmental conditions. As reported Rajput et al., 2014 \& Mukhdoomi et al., (2007) indicated the nature and genetic variability for the difference in these characters. And the difference in total fresh weight recorded maybe due to genetic factor and environmental factors.

\section{Total yield of radish per plant (tone/hectare)}

The data clearly showed that the total yields of radish per plant were found significant different among all the six varieties tried. The maximum total yield of radish per plant was recorded to Snow white $(69.47 \mathrm{t} / \mathrm{h})$ which was at par with Korean cross $(61.32 \mathrm{t} / \mathrm{h})$ while, Scarlet red globe $(8.67 \mathrm{t} / \mathrm{h})$ was recorded the minimum total yield of radish per plant. The yield of radish is significantly influenced due to environmental factors and temperature in particular. The strong vegetative growth in terms of height of the plant, number of leaves, and weight of radish plant per plant and germination percentage plays an important role in yield contribution. Parthasarathi et al., (1999) also indicated that the yield increase was mainly due to higher root weight and increase in length and diameter of the roots. Though Korean cross is an $\mathrm{F}_{1}$ hybrid with more genetic advancement in its characters but Snow white performed better in terms of seed germination compared with the other six varieties. So the varieties Snow white (69.47 $\mathrm{t} / \mathrm{h}$ ) produced the maximum yield and performed better than Korean cross (61.32 $\mathrm{t} / \mathrm{h})$ whereas the Local check $(51.02 \mathrm{t} / \mathrm{h})$ and Menu early $(50.79 \mathrm{t} / \mathrm{h})$ performance were average. The poor performance of the variety long red $(16.96 \mathrm{t} / \mathrm{h})$ mainly due to environment factor where most of plant blotting due to high temperature which leads to vegetative growth and seed formation 
which spoil the root formation. The poorest performance by Scarlet red globe among the six varieties was mainly due to poor germination percentage. Naseeruddin et al., (2011) and Rajput et al., (2014) concluded that the analysis of variance among different genotypes indicates highly significant differences in almost all the characters. These may be due the difference in genetic variability, heritability and genetic advance in different radish genotypes.

\section{Total yield of root without leaves (tone/hectare)}

The data clearly showed that the total yields of root were found significant different among all the six varieties tried. The maximum total yield of root was recorded to Korean cross $(46.91 \mathrm{t} / \mathrm{h})$ which was statistically at par with Snow white $(44.33 \mathrm{t} / \mathrm{h})$ while, Scarlet red globe $(5.99 \mathrm{t} / \mathrm{h})$ was recorded the minimum total yield of root. The yield of root is related which the root length and size. The variety Korean cross $(46.91 \mathrm{t} / \mathrm{h})$ being an $F_{1}$ showed better yield quantity as compared to the local check $(33.07 \mathrm{t} / \mathrm{h})$. Scarlet red globe performed poorly compared to the rest of other varieties due to mininature size in root and poor germination rate. These shows that genetic variability, heritability in superior gene characters and genetic advance plays a great role in determination on the yield of radish root yield. Similar findings were also found by Naseeruddin et al., (2011) which mention genetic advance in per cent of mean was maximum for root yield/plant.

\section{Dry matter}

\section{Dry weight of leaves per plant (g)}

The data clearly showed that the dry weight of leaves per plant was found significant different among all the six varieties studied. The maximum dry weight of leaves per plant was recorded to Snow white (10.i7 g), which was on par with the variety Menu early (10.14 g) while, Scarlet red globe (3.05 g) was recorded the minimum dry weight of leaves per plant.These differences in the dry weight of the leaves may be due to the dissimilarities in phenotypic and genotypic differences among the varieties. e.g. leaf length, nutrient content etc. The effect of environmental factor among the varieties may have also played a great role.

\section{Dry weight of radish root per plant (g)}

The data clearly showed that the total dry weight content of radish root per plant was found significant different among all the six varieties tried. The maximum total dry weight content of radish per plant was recorded to Korean cross (10.96 g), which was on par with the variety Menu early (10.54 g) while, Scarlet red globe $(2.77 \mathrm{~g})$ was recorded the minimum total dry weight content of radish per plant.The total dry weight content of radish root per plant were found to be varied significant due to different sources of organics, nutrients and their combination present in the root. The difference in root length and root diameter may be due to inherent characteristics of the varieties which is an factor for determination of dry weight of radish root per plant. These genetic variability and heritability may be the main factor responsible for the difference found in the total dry weight of radish. Similar finding was also reported by Mukhdoomi et al., (2007) which concluded that the analysis of variance revealed highly significant differences among genotypes for all the traits conducted in 23 different genotypes.

The data clearly showed that the total dry weight content of radish per plant was found significant different among all the six varieties tried. The maximum total dry weight content of radish per plant was recorded to 
Menu early (21.05 g), which was on par with the variety snow white (20.72 g) while, Scarlet red globe $(5.95 \mathrm{~g})$ was recorded the minimum total dry weight content of radish per plant. The total dry weights per plant were found to be significant due to different sources of organics and their combination. The increase in root length and root diameter may be due to inherent characteristics of the varieties which is a factor for determination of dry weight of the plant. These genetic variability and heritability may be the main factor responsible for the difference found in the total dry weight of radish.

The present study "Performance of different radish varieties under foothill region of Dehradun, Uttrakhand". The analysis revealed highly significant differences among genotypes for all the traits. The maximum total yield per plant was recorded to be variety Snow white $(69.47 \mathrm{t} / \mathrm{h})$ which was closely followed by Korean cross $(61.32 \mathrm{t} / \mathrm{h})$. And the minimum to be variety Scarlet red globe $(8.67 \mathrm{t} / \mathrm{h})$. In the trait conducted it is concluded that Snow white performed best among the six genotypes studied which was followed by Korean cross.

\section{References}

Anonymous. 2018. Indian Horticulture Database, National Horticulture Board, Government of India.

Crisp, P., 1995. Radish (Raphanus sativus). In: Evolution of crop plants. (Eds.): J. Smartt and N.W. Simmonds, 2nd ed. J. Smartt and N. W. Simmonds. Harlow, Essex: Longman Scientific and Technical, pp. 531 ISBN 0-521-086434.

Dilbag Singh and Rajinder Singh., 2012. Path coefficient analysis for seedling vigour in radish (Raphanus sativus L.) genotypes. HortFlora Research Spectrum, 1(4): 339-343.
Dongarwar, L. N., Kashiwar, S.R., Ghawade, S. M. and Dongarwar, U. R 2018. Varietal Performance of Radish (Raphanus sativus L.) Varieties in Black Soils of Vidharbha-Maharashtra, India Int.J.Curr.Microbiol.App.Sci 7(1): 491-501

Heiser, C. B., 1988. Aspects of un-conscious selection and the domesticated plants. Euphytica, 37: 77-81.

Lavanya, A. V. N, Sudha Vani, V., Reddy, P. S. S. and Chaitanya, K., 2014. Effect of sowing dates and spacing on growth and root yield of radish $\mathrm{Cv}$. Pusa chetki. Plant Archives Vol. 14 (1): 619-623

Mallikarjunarao, K., Singh, P. K., Vaidya, A., Pradhan, R. and Das, R. K., 2015 Genetic variability and selection parameters for different genotypes of radish (Raphanus sativus L.) under kashmir valley. Eco. Env. \& Cons. 21 (4): (361-364)

Mukhdoomi, M. I., Din, G., Ahmed, N., Hussain, K. And Gazala, N., 2007. Genetic variability and selection parameters for yield attributes in radish (Raphanus sativus L.). Asian J. Horti. 2: 2, 141- 143.

Naseeruddin, Kh, Pant, S.C., Tomar, Y.K., and Rana, D. K., 2011. Genetic variability and selection parameters for different genotypes of radish (Raphanus sativus L.) under valley condition of Uttarakhand - Progressive Horticulture. Vol. 43(2): 256-258.

Nisar, M. and Ghafoor, A., 2011. Linkage of a RAPD marker with powdery mildew resistance er-1gene in Pisum sativum L. Russian J. Genet, 47: 300-304.

Parthasarathi, Krishnappa, K. S., Chandra Gowda, M., Shiva Reddy, N. and Anjanappa, M., 1999. Growth and yield of certain varieties to varying levels of fertility. Karnataka; J.Agri.Sc, (1-4 combined):148-153. 
Rajput, R. N. and Pal A. K., 2014. Correlation and Path Analysis Studies in Radish Grown Under Partial Shade. Annals of Plant and Soil Research 16(2): 131-134.

Rubatzky, V.E. and Yamaguchi, M. 1997. World Vegetables: Principles, Production, and Nutritive Values. 2nd Edition, Chapman and Hall, USA, p. 843.

Werth, E. 1937. Abstammung and Heimat des Rettichs. Angew. Bot. 19: 194-205.

Yamane, K., Lü, N. and Ohnishi, O., 2009. Multiple origins and high genetic diversity of cultivated radish inferred from polymorphism in chloroplast simple sequence repeats. Breed. Sci., 59: 55-65.

Zaki, H.E.M., Takahata. Y and Yokoi. S., 2012. Analysis of the morphological and anatomical characteristics of roots in three radish (Raphanus sativus) cultivars that differ in root shape. Journal of horticultural science and biotechnology 87 (2): 172-178

\section{How to cite this article:}

Senjem Semba, Renu Rana, Tabalique Yumkhaibam and Md. Ramjan. 2019. Performance of Different Radish Varieties under Foothill Region Dehradun, Uttrakhand, India. Int.J.Curr.Microbiol.App.Sci. 8(07): 869-877. doi: https://doi.org/10.20546/ijcmas.2019.807.104 